DOI: https://doi.org/10.47405/mjssh.v7i1.1238

\begin{tabular}{|c|c|}
\hline 4.581 & Malaysian Journal of Social Sciences and Humanities (MJSSH) \\
\hline $\begin{array}{l}\text { Malaysian Journal of } \\
\text { socal s ciences and }\end{array}$ & Volume 7, Issue 1, January 2022 \\
\hline (MJ-SSH) & e-ISSN : 2504-8562 \\
\hline & $\begin{array}{l}\text { Journal home page: } \\
\text { www.msocialsciences.com }\end{array}$ \\
\hline
\end{tabular}

\title{
Cabaran dan Peluang Penempatan Guru Pendidikan Sejarah : Era Pasca Pandemik Covid-19
}

\author{
Lee Bih Ni ${ }^{1}$ \\ ${ }^{1}$ Faculty of Psychology and Education, Universiti Malaysia Sabah (UMS), Malaysia \\ Correspondence: Lee Bih Ni (leebihni@ums.edu.my)
}

\begin{abstract}
Abstrak
Artikel ini membincangkan cabaran dan peluang penempatan guru pendidikan sejarah: era pasca pandemik Covid-19. Kaedah penyelidikan kuantitatif deskriptif digunakan dalam kajian ini. Populasi bagi kajian ini adalah bertumpu kepada pelajar-pelajar Pendidikan Sejarah Fakulti Psikologi dan Pendidikan di sebuah universiti awam di Sabah yang sedang berada pada tahun pertama pengajian iaitu sesi 2020. Hasil kajian menunjukkan faktor dominan kekosongan jawatan dalam mencari penempatan untuk berkhidmat selain sekolah awam adalah mengajar pendidikan atau mata pelajaran Sejarah di sekolah menengah swasta. Walau bagaimanapun, pelajar-pelajar Pendidikan Sejarah tetap merasakan bersyukur jika mereka ditakdirkan untuk mengajar di sekolah bukan kerajaan dan bukan opsyen. Mereka juga bersedia menggalas tanggungjawab di tempat bertugas tanpa banyak rungutan. Memandangkan susah mendapat pekerjaan pada era pasca pandemik Covid-19. Menyedari keperluan mengikut semasa, pelajar-pelajar Pendidikan Sejarah juga bersedia melengkapkan diri dengan kemahiran meneroka pelbagai online atau non-online platform untuk mengembangkan kerjaya guru tanpa mengira opsyen.
\end{abstract}

Kata Kunci: cabaran penempatan, graduan pendidikan sejarah, kebolehpasaran, kesediaan mencari penempatan

\section{Challenges and Placement Opportunities for History Education Teachers: Post Covid-19}

\begin{abstract}
This paper discusses the challenges and opportunities of history education teacher placement: the postpandemic era of Covid-19. Descriptive quantitative research methods were used in this study. The population for this study is focused on students of History Education Faculty of Psychology and Education at a public university in Sabah who are in the first year and second year of study that is session $2020 \& 2021$. The results show that the dominant factor of vacancies in finding placements to serve other than public schools is teaching education or History subjects in private secondary schools. However, History Education students still feel grateful if they are destined to teach in non-government and non-option schools. They are also willing to shoulder responsibilities in the workplace without much grievance. Given the difficulty of getting a job in the post-pandemic era of Covid-19. Recognizing the current needs, History Education students are also willing to equip themselves with the skills to explore various online or non-online platforms to develop a teacher career regardless of options.
\end{abstract}


Keywords: placement challenges, history education graduates, marketability, willingness to seek placement

\section{Pengenalan}

Kementerian Pendidikan Malaysia (KPM) bakal membuat pengambilan khas secara one-off melibatkan sejumlah 18,702 guru bagi gred DG41 yang turut dibuka kepada graduan bukan bidang pendidikan bagi mengatasi isu kekurangan guru di negara ini. Menteri Pendidikan, Senator Datuk Dr Mohd Radzi Jidin, berkata langkah itu bertujuan menampung kekurangan guru di Sabah, Sarawak, Selangor dan Johor selain usaha mencapai perancangan di bawah Pelan Pemulihan Negara. Menurutnya, pengambilan tersebut antara lain akan memberi tumpuan mengisi kekosongan guru bagi mata pelajaran tertentu yang menyebabkan wujudnya jurang tenaga pengajar hingga menjadi cabaran utama sistem pendidikan negara masa kini. Kementerian Pendidikan akan bekerjasama dengan Suruhanjaya Perkhidmatan Pendidikan (SPP) untuk memastikan perancangan lebih teratur dengan pendekatan baharu oleh kementerian bersama SPP dan Jabatan Perkhidmatan Awam (JPA). Iklan pengambilan akan dikeluarkan oleh SPP pada 7 Julai 2021 dan penempatan pula bermula Oktober secara berperingkat. Kekurangan guru bagi negeri-negeri terlibat membabitkan sekolah rendah dan sekolah menengah khususnya dalam mata pelajaran tertentu seperti Bahasa Inggeris, Bahasa Melayu dan Pendidikan Agama Islam. Bagi sekolah rendah, terdapat lima mata pelajaran mengalami kekurangan guru iaitu Bahasa Inggeris, Sejarah, Pendidikan Khas, Pendidikan Agama Islam dan Teknologi Maklumat dan Komunikasi. Bagi sekolah menengah pula, kekurangan guru bagi Bahasa Melayu, Bahasa Inggeris, Pendidikan Khas, Pendidikan Agama Islam serta Reka Bentuk dan Teknologi. Melalui pendekatan pengambilan baharu menerusi kerjasama SPP dan JPA, akan memberi peluang kepada graduan yang berminat dan berkelayakan seperti yang ditetapkan. Ramai tertanya-tanya mereka ada kelayakan dalam bidang pendidikan tetapi tidak dipanggil untuk mengajar. Dalam konteks ini adalah kerana ketidakpadanan mata pelajaran. Bekalan (graduan pendidikan) yang ada amat terhad. Bagaimanapun bagi pengambilan ini akan utamakan graduan pendidikan tapi dalam masa sama pendekatan baharu digunakan supaya dapat mengatasi isu ketidakpadanan guru bagi mata pelajaran tertentu (Hidayah, 2021).

Perbelanjaan kerajaan yang besar diperuntukkan setiap tahun untuk mengembangkan pengajian tinggi di Malaysia. Di samping pemberian wang, bilangan institusi pengajian tinggi yang terus meningkat adalah petunjuk penting bagi usaha negara dalam memberikan peluang yang lebih besar bagi akses warganya ke pengajian tinggi. Walau bagaimanapun, masalah pengangguran graduan dan kesukaran mendapatkan pekerjaan adalah masalah yang memberi menimbulkan persepsi negatif terhadap dasar pembangunan pendidikan tinggi negara. Dari segi pembangunan modal insan, kenaikan perbelanjaan wang serta peningkatan jumlah institusi pengajian tinggi merupakan petunjuk positif untuk mewujudkan peluang yang lebih besar bagi masyarakat untuk mendapatkan pendidikan tinggi dan oleh itu pertumbuhan pengumpulan modal insan negara. Walau bagaimanapun, melainkan jika peningkatan jumlah lulusan itu sesuai dengan peluang pekerjaan tahap pendidikan dan bidang pembelajaran mereka yang sama, ini boleh bermakna bahawa pendidikan tinggi negara kurang berjaya dalam menghasilkan tenaga kerja yang sesuai dengan keperluan pasaran. Ini ialah dilema Malaysia dikongsi oleh negaranegara membangun yang sama apabila peningkatan pelajar berpendidikan tinggi tidak dapat memenuhi keperluan pasaran pekerjaan yang ada. Perbezaan penawaran permintaan buruh siswazah ini menimbulkan banyak masalah dan tidak kurang juga peranan institusi pengajian tinggi dan program pengajian yang ditawarkan tetapi juga kualiti graduan. Objektif utama artikel ini adalah untuk membincangkan cabaran dan peluang penempatan sebagai pemacu meningkatkan keupayaan penempatan graduan Pendidikan Sejarah pasca pandemik Covid-19. Kajian kes yang melibatkan pelajar Pendidikan Sejarah akan dapat memberikan maklumat yang relevan untuk menilai aspek pengembangan amalan kebolehpasaran bagi graduan Pendidikan Sejarah institusi pengajian tinggi, khususnya di Fakulti Psikologi dan Pendidikan, Universiti Malaysia Sabah dalam memenuhi keperluan pasaran pekerjaan dengan tepat. 


\section{Kajian Literatur}

Kebolehpasaran adalah konsep yang sukar untuk diukur dan ditakrifkan (Harvey, 2001; Pegg, Waldock, Hendy-Isaac \& Lawton, 2012; Sewell \& Dacre Pool, 2010). Konsep kebolehkerjaan nampaknya berkembang seiring dengan perubahan corak kerja dan model tenaga kerja. McQuaid dan Linda (2005) menyatakan bahawa walaupun kebolehkerjaan adalah konsep yang tidak jelas pada dekad yang lalu, ia kini memainkan peranan penting dalam menentukan dasar pasaran buruh Inggeris, di beberapa negara Eropah dan negara-negara lain juga. Kebolehkerjaan sekarang dilihat sebagai sasaran utama dalam kebanyakan dasar pasaran tenaga kerja dan strategi tenaga kerja di kebanyakan negara terutama untuk kebolehpasaran graduan. Lulusan universiti memegang kedudukan tinggi dalam ekonomi dan banyak negara menganggap mereka sebagai golongan elit sosial dan akibatnya sebagai kumpulan kerja untuk mengakses pendapatan tinggi yang berpotensi memenuhi kerjaya pekerja berpengetahuan.

Walaupun begitu, terdapat perbezaan di kalangan graduan mengenai hasil pasaran pekerja mereka. Kajian menunjukkan hubungan antara faktor individu dan faktor pasaran yang mempengaruhi kebolehkerjaan individu tertentu. Kebolehpasaran graduan tidak hanya ditentukan sebagai hasil program pengajian khusus disiplin atau pengajian profesional, tetapi juga kemampuan graduan untuk mempromosikan kemahiran yang lebih luas seperti komunikatif, penyelesaian masalah, kemahiran interaktif, menunjukkan inisiatif dan kecekapan. Selanjutnya, kebolehkerjaan juga merangkumi aspek sikap dan sifat peribadi kesetiaan, komitmen, kejujuran, ketepatan masa dan integriti. Ini menunjukkan bahawa kebolehkerjaan merangkumi aspek tindakan proaktif, sikap pengurusan peribadi dan kemampuan pengurusan kerjaya individu sebagai usaha untuk memperoleh kerjaya yang diinginkan (Clarke, 2008).

Kebolehpasaran graduan merujuk kepada kemahiran yang perlu dimiliki oleh graduan untuk mendapatkan dan mengekalkan pekerjaan (dalam Litisha \& Surina, 2010) melalui pembelajaran kemahiran baru untuk fungsi yang berbeza seperti yang dituntut oleh majikan atau industri (Malaysia (2010a)). Manakala menurut Hillage dan Pollard (1998), kemampuan bekerja mempunyai kemampuan untuk mendapatkan pekerjaan pertama, menyimpannya, dan memperoleh pekerjaan baru jika diperlukan. Harvey (2001) mendefinisikan kebolehkerjaan siswazah sebagai kemampuan siswazah untuk menunjukkan kualiti yang diperlukan oleh majikan untuk keperluan organisasi pada masa hadapan. Kemahiran kerja adalah satu set pencapaian, pemahaman, dan sikap / kualiti peribadi yang menandakan individu berpotensi lebih mampu mendapatkan pekerjaan yang diinginkan dan berjaya dalam pemilihan kerjaya. Secara amnya, keterampilan kerja adalah aspek kemahiran dan pengetahuan yang perlu dimiliki oleh pelajar untuk melengkapkannya untuk memenuhi pelbagai tuntutan pekerjaan di pasaran buruh setelah mereka menamatkan pengajian.

Aspek kebolehpasaran graduan pembangunan adalah teras penting dalam pengajian tinggi untuk membolehkan mereka bekerja dengan baik di pasaran pekerjaan. Sebagai tambahan kepada kemahiran pengetahuan, majikan juga menuntut keperibadian yang baik dari graduan. Antara faktor penting yang perlu dipertimbangkan adalah kemampuan untuk menyesuaikan diri dengan budaya firma dan keinginan untuk belajar secara berterusan (Cai, 2012; Bui \& Porter, 2010). Eric (2015) meneroka jurang antara harapan industri dan persepsi kumpulan kemahiran graduan kejuruteraan di wilayah Timur Tengah dan Afrika Utara. Mereka mengukur kepentingan bahawa pengurus jurutera meletakkan 36 kemahiran yang relevan dengan jurutera. Hasil menunjukkan jurang yang signifikan antara harapan dan kepuasan pengurus dengan semua 36 kemahiran. Para pengurus merasakan bahawa graduan memerlukan peningkatan komunikasi, pengurusan masa, dan pembelajaran berterusan. Pengurus melaporkan bahawa lulusan kejuruteraan baru-baru ini menunjukkan kesediaan keseluruhan untuk pekerjaan. Yee, Kui, Wei (2015) mendapati bahawa majikan menuntut lebih bebas dan pemimpin, bukannya pengikut, dan lulusan yang lebih cenderung kepada pengurusan. Pasaran buruh yang kompetitif memerlukan kerjasama dan persefahaman antara firma dan universiti. Sebagai tindak balas, universiti dapat mengembangkan kurikulum dalam memupuk graduan yang cenderung kepemimpinan di bawah penyampaian akademik yang berpengetahuan mengenai keperluan pasaran semasa. 
Kemahiran kebolehpasaran memainkan peranan penting dalam aliran pekerjaan semasa. Walau bagaimanapun, semua kajian menilai graduan dan mereka yang telah lulus. Terdapat sedikit kajian yang melihat masalah di peringkat sarjana. Untuk mengisi kekosongan keadaan, kajian ini akan melihat masalah merujuk kepada sarjana sebagai unit analisis kerana masalah kebolehpasaran graduan menyebabkan kenaikan kadar pengangguran graduan dan memberi kesan negatif terhadap imej universiti sebagai institusi pengajian tinggi negara, pembangunan modal insan, pembangunan ekonomi dan pelaburan dalam pengajian tinggi. Kemahiran yang akan diperoleh pelajar semasa pendidikan mereka dan yang akan berguna bagi mereka dalam kerjaya masa depan mereka. Dalam kes sejarah, kemahiran yang dikenal pasti adalah disiplin diri, arahan diri, kebebasan fikiran dan inisiatif, kemampuan untuk bekerja dengan orang lain, kemampuan untuk mengumpulkan, mengurus dan menggunakan bukti dan maklumat, kemampuan analisis dan penyelesaian masalah, baik kemahiran lisan dan penulisan, integriti intelektual dan kematangan, empati dan wawasan imaginatif. Pada hakikatnya, latihan penanda aras adalah latihan yang dikendalikan oleh kerajinan, yang pasti memusatkan perhatian pada kemahiran yang dijaga oleh penjaga disiplin itu sebagai sesuatu yang melekat padanya dan mengharapkan pelajar memperolehnya setelah tamat pengajian.

\section{Pernyataan Masalah}

Program Ijazah Sarjana Pendidikan Dengan Kepujian (Sejarah) kini merupakan di antara program yang menjadi pilihan utama pelajar untuk memasuki Institusi Pengajian Tinggi (IPT) tidak kira awam mahupun swasta. Namun, adakah dengan hanya menerima segulung ijazah dalam bidang pendidikan Sejarah menjadikan bakal guru Sejarah ini benar-benar bersedia untuk berkhidmat dalam profesion perguruan yang penuh dengan cabaran ini. Hal ini kerana, walaupun terdapat ramai guru pelatih Sejarah yang dilahirkan daripada institusi pendidikan namun menurut Menteri Pelajaran Dr. Mohd Radzi Bin Md Jidin (Faris, 2021), masih terdapat sekolah-sekolah yang kekurangan guru termasuk guru Sejarah. Beliau turut menyatakan bahawa terdapat guru yang tidak ditawarkan bertugas di kawasan bandar atau luar bandar. Ihsan (2021) menyatakan bahawa bagi memperoleh sumber manusia pendidikan berketerampilan, negara perlu melatih dan membekalkan pendidik yang secukupnya. Ini menunjukkan negara yang maju bergantung kepada sumber manusia yang berketerampilan dan dalam usaha ke arah itu, guru yang merupakan pendidik perlulah diberi peluang dalam usaha mencapai matlamat tersebut. Penempatan di sini adalah dikaitan dengan peluang berkhidmat. Komponen penempatan ini meliputi aspek Opsyen Sejarah, kemahiran pedagogi dan juga sikap guru (Mudhovozi, 2021). Bakal-bakal guru Sejarah membina kompetensi diri semasa mereka melalui proses pembelajaran di universiti-universiti atau institut-institut pendidikan. Kompentensi penempatan yang dikuasi oleh bakal guru Sejarah ini akan membantu membentuk keputusan diri guru dan juga membina kecemerlangan para pelajar (Embi, 2011). Fakulti Psikologi dan Pendidikan, Universiti Malaysia Sabah adalah merupakan organisasi yang melatih bakal-bakal guru Sejarah dalam bidang pendidikan Sejarah. Isu kesediaan untuk mencari tempat atau ditempatkan di sekolah-sekolah awam atau swasta di bandar atau luar bandar adalah merupakan antara elemen kesediaan yang perlu ada dalam diri bakal guru Sejarah. Ianya ada kaitan dengan sikap dan kesediaan bakal guru untuk mencari kerja dan menyumbang kepada pembangunan modal insan khususnya di bandar atau luar bandar. Oleh yang demikian, adakah guru pelatih daripada Fakulti Psikologi dan Pendidikan, Universiti Malaysia Sabah bersedia mencari kerja atau ditempatkan untuk berkhidmat di sekolah-sekolah awam atau swasta di kawasan luar bandar dan kawasan bukan pilihan? Maka, kajian ini dijalankan adalah bagi mengetahui tahap kesediaan bakal pendidik Sejarah dalam mencari kerja dan memberi khidmat tidak kira di manamana sekalipun mereka berada selepas tamat pengajian.

\section{Objektif Kajian}

i. $\quad$ Mengenal pasti cabaran dan peluang penempatan guru pendidikan Sejarah di era pasca pandemik Covid-19.

ii. Mengenal pasti kerangka konseptual untuk mengembangkan penempatan graduan Pendidikan Sejarah. 
iii. Mengenal pasti cabaran dan peluang penempatan sebagai pemacu meningkatkan keupayaan penempatan graduan Pendidikan Sejarah pasca pandemik Covid-19.

\section{Kerangka Konsep Kajian}

Kerangka kajian seperti Rajah 1 berperanan untuk menjelaskan tentang konsep sebenar kajian yang dijalankan. Kerangka kajian lazimnya disampaikan dalam bentuk peta minda bagi memudahkan pembacaan bagi memahami idea keseluruhan kajian.

Rajah 1: Kerangka Konsep Kajian

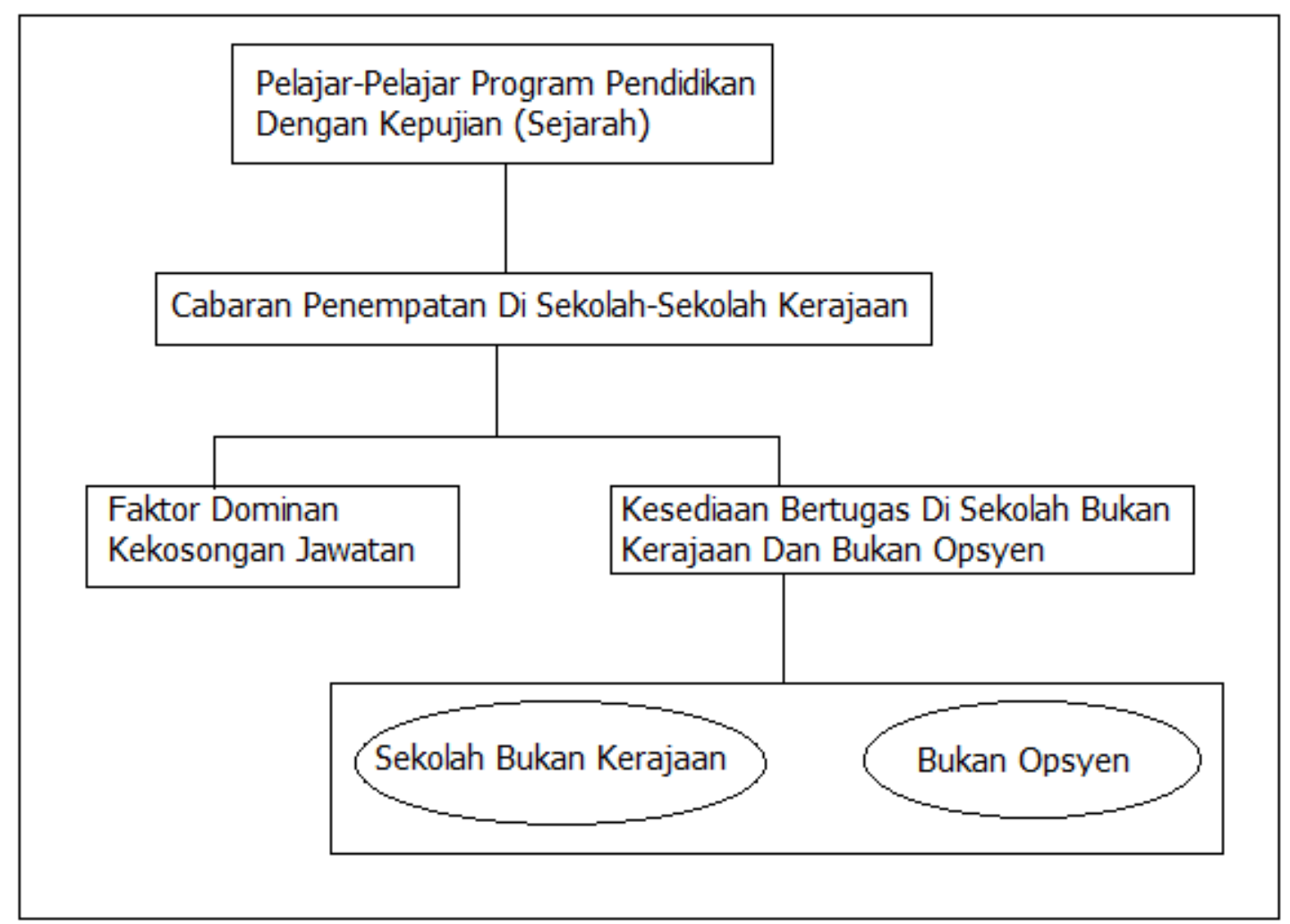

\section{Metod Kajian}

Kaedah penyelidikan kuantitatif deskriptif digunakan dalam kajian ini. Ia bertujuan untuk menggambarkan secara tepat dan sistematik populasi, keadaan atau fenomena. Ia dapat menjawab persoalan apa, di mana, bila dan bagaimana cabaran dan peluang penempatan guru pendidikan Sejarah di era pasca pandemik Covid-19. Reka bentuk penyelidikan deskriptif dapat menggunakan pelbagai kaedah penyelidikan untuk menyelidiki satu atau lebih pemboleh ubah.

Populasi bagi kajian ini adalah bertumpu kepada pelajar-pelajar Pendidikan Sejarah Fakulti Psikologi dan Pendidikan, Universiti Malaysia Sabah (UMS) yang sedang berada pada tahun pertama dan tahun kedua pengajian iaitu sesi 2020 \& 2021. Jumlah keseluruhan pelajar-pelajar Pendidikan Sejarah tahun pertama dan kedua ini adalah seramai 45 orang pelajar. Tujuan mengambil pelajar tahun pertama ini sebagai responden adalah kerana mereka telah mengikuti keseluruhan program Pendidikan Sejarah secara "Open Market" yang terdapat di UMS ini. Mereka merupakan bakal guru yang akan mencari penempatan untuk mengajar kelak. Berdasarkan jadual tersebut, jika populasi kajian adalah seramai 45 orang, maka pengkaji perlu mengambil kesemua 45 orang responden untuk dijadikan sampel dalam kajian. Walau bagaimanapun, sampel kajian seramai 45 orang ini dipilih secara bertujuan daripada jumlah keseluruhan pelajar Pendidikan Sejarah tahun pertama dan kedua pengajian iaitu sesi 2020 \& 
2021 (Bar, 2021). Dalam membina soal selidik ini, pengkaji menggunakan item yang berbentuk senarai semak iaitu kaedah penggunaan Skala Likert. Item jenis skala Likert pula mengehendaki responden menjawab dengan menandakan satu pilihan jawapan yang mengikut aras satu hingga lima seperti yang ditunjukkan pada jadual 1.1 berikut:

Jadual 1 : Skala Likert

\begin{tabular}{llllll}
\hline Skala Likert & $\mathbf{1}$ & $\mathbf{2}$ & $\mathbf{3}$ & $\mathbf{4}$ & $\mathbf{5}$ \\
\hline Maklum Balas & $\begin{array}{l}\text { Sangat Tidak } \\
\text { Setuju }\end{array}$ & Tidak Setuju & Kurang Setuju & Setuju & Sangat Setuju \\
\hline
\end{tabular}

\section{Hasil Kajian}

Dalam kajian ini, jumlah keseluruhan responden yang terlibat adalah seramai 45 orang. Berdasarkan Jadual 2, data menunjukkan sebanyak 100 peratus adalah pelajar-pelajar Program Pendidikan Dengan Kepujian (Sejarah) Fakulti Psikologi dan Pendidikan, Universiti Malaysia Sabah (UMS) yang sedang berada di tahun pertama dan kedua pengajian iaitu sesi 2020 \& 2021. Mereka dijangka bergraduasi pada tahun $2024 \& 2025$.

\section{Analisis Berkenaan Dengan Faktor Dominan Kekosongan Jawatan Dalam Mencari Penempatan Untuk Berkhidmat}

Jadual 2 : Faktor Dominan Kekosongan Jawatan Dalam Mencari Penempatan Untuk Berkhidmat Selain Sekolah Awam

\begin{tabular}{llll}
\hline No Item & Item & Kekerapan & $\begin{array}{l}\text { Peratus } \\
(\%)\end{array}$ \\
\hline 1. & $\begin{array}{l}\text { Kekosongan Jawatan Pendidikan } \\
\text { Sejarah }\end{array}$ & 21 & 46.67 \\
& $\begin{array}{l}\text { (Sekolah Menengah Swasta) } \\
\text { Kekosongan Jawatan Pendidikan } \\
\text { Sejarah }\end{array}$ & 12 & 26.66 \\
2. & Sekolah Rendah Swasta) & & \\
& $\begin{array}{l}\text { Kekosongan Jawatan Pendidikan } \\
\text { (Sekolah Menengah Swasta) }\end{array}$ & 6 & 13.32 \\
3. & $\begin{array}{l}\text { Kekosongan Jawatan Pendidikan } \\
\text { (Sekolah Rendah Swasta) }\end{array}$ & 2 & 4.45 \\
4. & $\begin{array}{l}\text { Kekosongan Jawatan Bukan } \\
\text { Pendidikan di sektor awam dan swas }\end{array}$ & 4.45 \\
5. & $\begin{array}{l}\text { Bekerja sendiri } \\
\text { Jumlah }\end{array}$ & 2 & 4.45 \\
6. & 45 & 100 \\
\hline
\end{tabular}

Berdasarkan Jadual 2 diatas dan Rajah 2 dibawah, didapati nilai peratusan yang diperoleh menunjukkan seramai 21 orang mewakili 46.67 peratus daripada keseluruhan responden memilih ditempatkan untuk mengajar Sejarah di sekolah menengah swasta. Manakala, sebanyak 26.66 peratus iaitu 12 orang pula memilih ditempatkan untuk mengajar Sejarah di sekolah rendah swasta, diikuti seramai 6 orang yang mewakili 13.32 peratus daripada responden pula memilih ditempatkan untuk mengajar subjek selain Sejarah di sekolah menengah swasta. Seterusnya 4.45 peratus iaitu seramai 2 orang responden memilih ditempatkan untuk mengajar subjek selain Sejarah di sekolah rendah swasta. Bagi faktor kekosongan jawatan bukan pendidikan di sektor awam mahupun swasta, dan bekerja sendiri masing-masing adalah sebanyak 4.45 peratus iaitu seramai 2 orang. 
DOI: https://doi.org/10.47405/mjssh.v7i1.1238

Rajah 2: Graf Peratus Bagi Faktor Dominan Kekosongan Jawatan

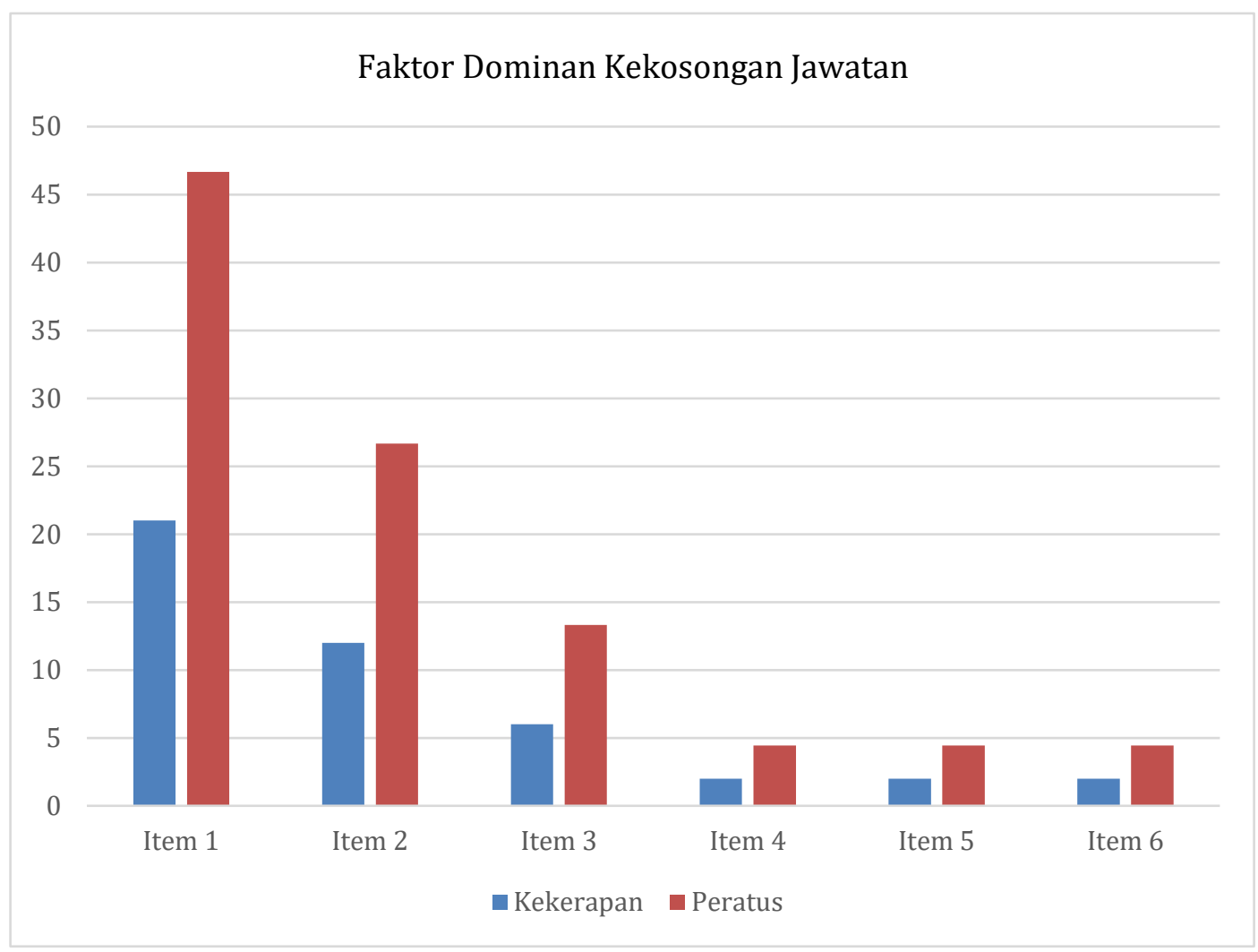

\section{Analisis Berkenaan Kesediaan Penempatan Di Sekolah Bukan Kerajaan}

Berdasarkan Jadual 3, dilihat purata keseluruhan nilai skor min bagi kesediaan mengajar di sekolah bukan kerajaan adalah tinggi iaitu 3.97 dengan sisihan piawai 0.772. Purata yang diperoleh menunjukkan secara keseluruhannya pelajar-pelajar Pendidikan Sejarah Fakulti Psikologi dan Pendidikan, UMS mempunyai kesediaan pada tahap yang tinggi dari aspek kesediaan mengajar di sekolah bukan kerajaan. Berdasarkan item-item yang terdapat dalam aspek penerimaan, item Bersedia meneroka pelbagai online atau non-online platform untuk mengembangkan kerjaya guru menunjukkan skor min yang tertinggi iaitu sebanyak 4.28 dengan sisihan piawai 0.619. Manakala item bersedia untuk membuat penyesuaian diri setelah mendaftar berkhidmat di sekolah bukan kerajaan merupakan skor min yang terendah iaitu 3.80 dengan sisihan piawai 0.943 .

Jadual 3 : Kesediaan Penempatan di Sekolah Bukan Kerajaan

\begin{tabular}{|c|c|c|c|c|}
\hline $\begin{array}{l}\text { No } \\
\text { Item }\end{array}$ & Item & Skor Min & Sisihan Piawai & $\begin{array}{l}\text { Tafsiran Skor } \\
\text { Min }\end{array}$ \\
\hline 1 & $\begin{array}{l}\text { Boleh terima mengajar di } \\
\text { sekolah bukan kerajaan } \\
\text { berbanding di sekolah } \\
\text { kerajaan }\end{array}$ & 3.97 & 0.764 & Tinggi \\
\hline 2 & $\begin{array}{l}\text { Merasakan bersyukur jika } \\
\text { mendapat tempat untuk } \\
\text { mengajar di sekolah bukan } \\
\text { kerajaan. }\end{array}$ & 3.89 & 0.834 & Tinggi \\
\hline 3 & $\begin{array}{l}\text { Bersedia untuk membuat } \\
\text { penyesuaian diri setelah } \\
\text { mendaftar berkhidmat di } \\
\text { sekolah bukan kerajaan }\end{array}$ & 3.80 & 0.943 & sederhana \\
\hline
\end{tabular}



DOI: https://doi.org/10.47405/mjssh.v7i1.1238

\begin{tabular}{|c|c|c|c|c|}
\hline 4 & $\begin{array}{l}\text { Bersedia berkhidmat di } \\
\text { sekolah bukan kerajaan } \\
\text { tanpa sebarang rungutan }\end{array}$ & 3.92 & 0.781 & Tinggi \\
\hline 5 & $\begin{array}{l}\text { Menerima penempatan } \\
\text { mengajar yang ditawarkan } \\
\text { walaupun sekolah bukan } \\
\text { kerajaan dan terpaksa } \\
\text { berjauhan dengan keluarga }\end{array}$ & 3.97 & 0.688 & Tinggi \\
\hline 6 & $\begin{array}{l}\text { Bersedia meneroka } \\
\text { pelbagai online atau non- } \\
\text { online platform untuk } \\
\text { mengembangkan kerjaya } \\
\text { guru. Contoh: youtube, tik } \\
\text { tok, google meet, google } \\
\text { classroom, pusat tuisyen, } \\
\text { taska, tadika dan lain-lain. } \\
\text { Purata Keseluruhan }\end{array}$ & 4.28 & 0.619 & Tinggi \\
\hline
\end{tabular}

Rajah 3 : Graf Skor Min Bagi Kesediaan Mengajar di Sekolah Bukan Kerajaan

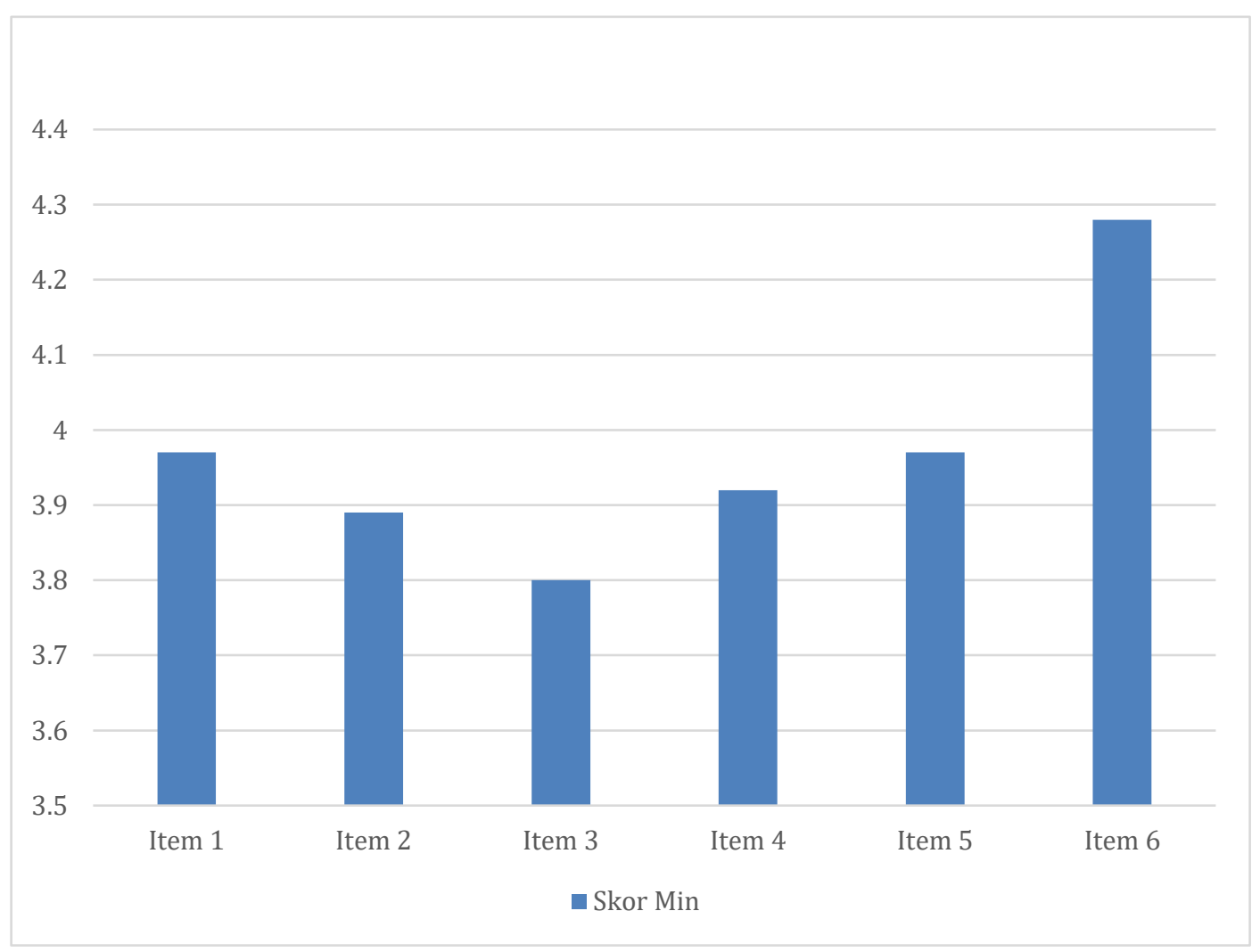


DOI: https://doi.org/10.47405/mjssh.v7i1.1238

Rajah 4: Boxplot Skor Min Bagi Kesediaan Mengajar di Sekolah Bukan Kerajaan

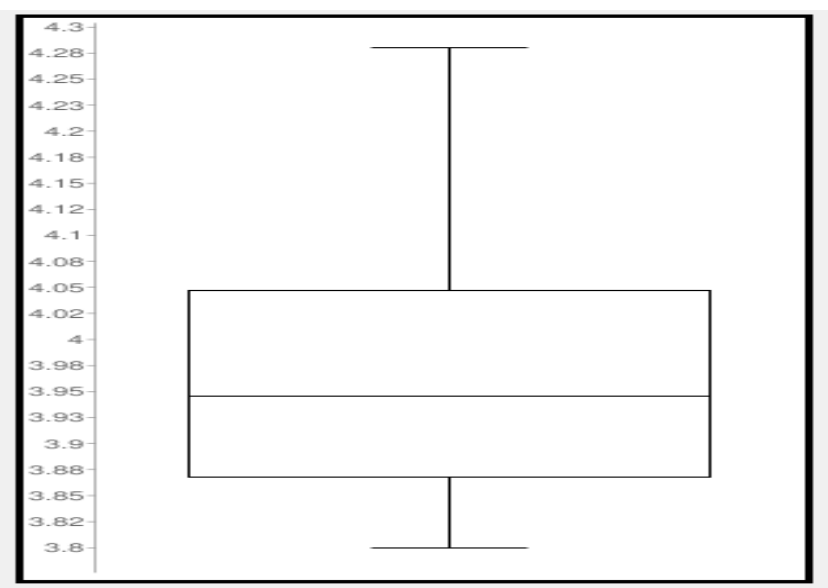

\section{Analisis Berkenaan Kesediaan Mengajar Mata Pelajaran Bukan Opsyen}

Berdasarkan Jadual 4, dilihat purata keseluruhan nilai skor min bagi mengajar mata pelajaran bukan opsyen adalah tinggi iaitu 3.95 dengan sisihan piawai 0.774. Purata yang diperoleh menunjukkan secara keseluruhannya pelajar-pelajar Pendidikan Sejarah Fakulti Psikologi dan Pendidikan, UMS mempunyai kesediaan pada tahap yang tinggi dari aspek kesediaan mengajar mata pelajaran bukan opsyen di sekolah kerajaan mahupun bukan kerajaan. Berdasarkan item-item yang terdapat dalam aspek penerimaan, item bersedia meneroka pelbagai online atau non-online platform untuk mengembangkan kerjaya guru tanpa mengira menunjukkan skor min yang tertinggi iaitu sebanyak 4.26 dengan sisihan piawai 0.621. Manakala item bersedia untuk membuat penyesuaian diri untuk mengajar mata pelajaran bukan opsyen merupakan skor min yang terendah iaitu 3.78 dengan sisihan piawai 0.945 .

Jadual 4 : Kesediaan Mengajar Mata Pelajaran Bukan Opsyen

\begin{tabular}{|c|c|c|c|c|}
\hline $\begin{array}{l}\text { No } \\
\text { Item }\end{array}$ & Item & Skor Min & Sisihan Piawai & $\begin{array}{l}\text { Tafsiran Skor } \\
\text { Min }\end{array}$ \\
\hline 1 & $\begin{array}{l}\text { Boleh terima mengajar mata } \\
\text { pelajaran bukan opsyen di } \\
\text { sekolah bukan kerajaan } \\
\text { mahupun sekolah kerajaan }\end{array}$ & 3.95 & 0.766 & Tinggi \\
\hline 2 & $\begin{array}{l}\text { Merasakan bersyukur jika } \\
\text { berpeluang mengajar mata } \\
\text { pelajaran bukan opsyen di } \\
\text { sekolah bukan kerajaan } \\
\text { mahupun sekolah kerajaan }\end{array}$ & 3.87 & 0.836 & Tinggi \\
\hline 3 & $\begin{array}{l}\text { Bersedia membuat } \\
\text { penyesuaian diri untuk } \\
\text { mengajar mata pelajaran } \\
\text { bukan opsyen di sekolah } \\
\text { bukan kerajaan mahupun } \\
\text { sekolah kerajaan }\end{array}$ & 3.78 & 0.945 & sederhana \\
\hline 4 & $\begin{array}{l}\text { Bersedia mengajar mata } \\
\text { pelajaran bukan opsyen di } \\
\text { sekolah bukan kerajaan } \\
\text { mahupun sekolah kerajaan } \\
\text { tanpa sebarang rungutan }\end{array}$ & 3.90 & 0.783 & Tinggi \\
\hline
\end{tabular}



DOI: https://doi.org/10.47405/mjssh.v7i1.1238

\begin{tabular}{|c|c|c|c|c|}
\hline 5 & $\begin{array}{l}\text { Menerima tanggungjawab } \\
\text { mengajar mata pelajaran } \\
\text { bukan opsyen di sekolah } \\
\text { bukan kerajaan mahupun } \\
\text { sekolah kerajaan } \\
\text { walaupun terpaksa belajar } \\
\text { ilmu berkenaan subjek baru } \\
\text { yang diajar }\end{array}$ & 3.95 & 0.690 & Tinggi \\
\hline 6 & $\begin{array}{l}\text { Bersedia meneroka pelbagai } \\
\text { online atau non-online } \\
\text { platform untuk } \\
\text { mengembangkan kerjaya } \\
\text { guru tanpa mengira opsyen. } \\
\text { Contoh: youtube, tik tok, } \\
\text { google meet, google } \\
\text { classroom, pusat tuisyen, } \\
\text { taska, tadika dan lain-lain. } \\
\text { Purata Keseluruhan }\end{array}$ & 4.26 & 0.621 & Tinggi \\
\hline
\end{tabular}

Rajah 5 : Graf Skor Min Bagi Kesediaan Mengajar Mata Pelajaran Bukan Opsyen

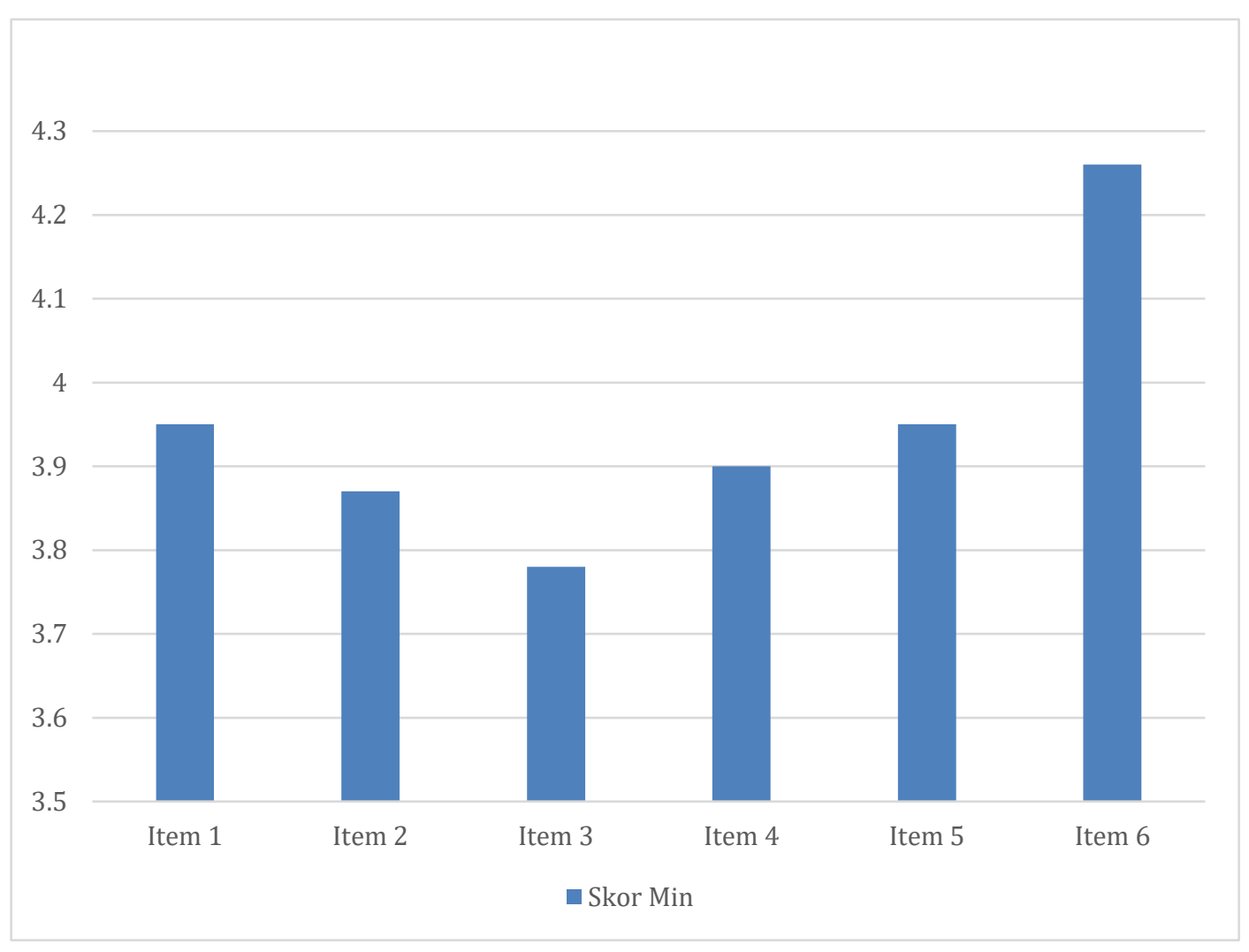


DOI: https://doi.org/10.47405/mjssh.v7i1.1238

Rajah 6: Skor Min Bagi Kesediaan Mengajar Mata Pelajaran Bukan Opsyen

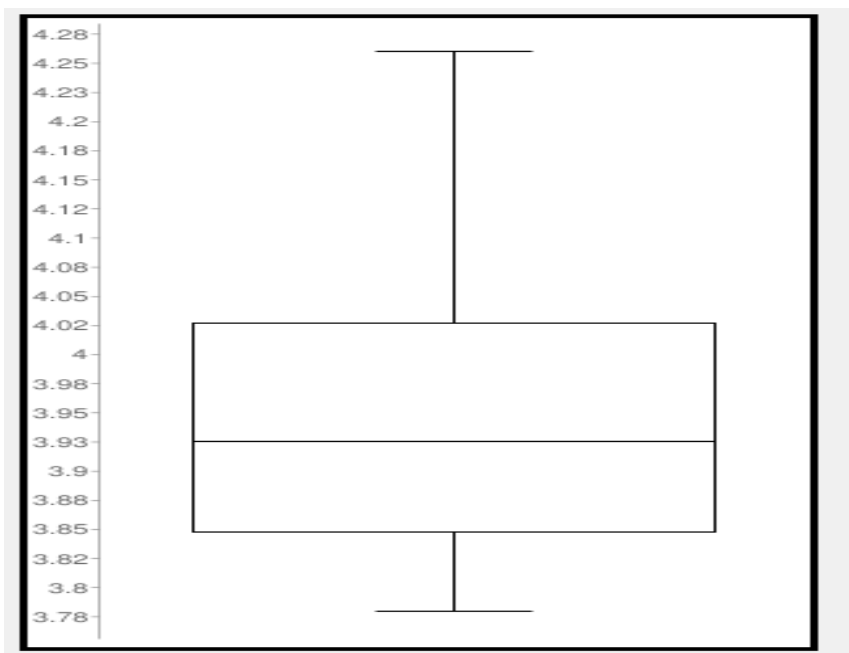

\section{Perbincangan}

\section{Faktor Dominan Kekosongan Jawatan Dalam Mencari Penempatan Untuk Berkhidmat Selain Sekolah Awam}

Berdasarkan hasil kajian, didapati bahawa hampir separuh pelajar-pelajar Pendidikan Sejarah Fakulti Psikologi dan Pendidikan, UMS iaitu 46.67 peratus yang mewakili 45 orang memilih untuk mengajar pendidikan atau mata pelajaran Sejarah di sekolah menengah swasta. Hal ini mungkin disebabkan mereka telah biasa dengan mind-set Program Pendidikan Sejarah di peringkat awal pengajian. Mereka memilih untuk mengajar pendidikan atau mata pelajaran Sejarah di sekolah rendah swasta, iaitu 26.66 peratus. Faktor ketiga adalah memilih untuk mengajar mata pelajaran selain Sejarah di sekolah menengah dan rendah swasta. Secara positif, ia dilihat sebagai keperluan kerana pada hari ini seseorang guru perlu berpengetahuan pelbagai disiplin menjalani multi-task di sekolah. Seterusnya pelajar-pelajar Pendidikan Sejarah memilih untuk menceburi bidang bukan pendidikan di sektor awam dan swasta. Hal ini kerana mungkin mereka memikirkan mengenai kelangsungan hidup untuk mendapatkan satu pekerjaan. Peratusan yang memberangsangkan (4.45\%) terhadap pemilihan untuk bekerja sendiri menjadi bukti ada pelajar Pendidikan Sejarah bersedia menjadi pengusaha dalam bidang pendidikan atau bukan pendidikan secara online mahupun bukan online di masa hadapan jika mereka tiada peluang mengajar di sekolah kerajaan atau sekolah swasta.

Nilai kritikal $p$ (kebarangkalian) dan aras keertian: $p=0.005$ (tahap kepentingan statistik 99.5\%) Darjah kebebasan: darjah kebebasan $=0$. Kesimpulan adalah nampaknya terdapat korelasi positif yang sangat kuat Nilai Rs (+1). Terdapat kebarangkalian $0.5 \%$ bahawa hipotesis nol adalah betul, $\mathrm{p}=0.005$ (tahap kepentingan statistik 99.5\%). Oleh itu, pengkaji mesti menerima hipotesis alternatif (bahawa terdapat korelasi positif yang sangat kuat antara kumpulan data kajian) dan menolak hipotesis nol bahawa tidak ada korelasi. Korelasi tidak menunjukkan sebab-akibat. Satu pemboleh ubah tidak boleh menyebabkan yang lain. 
Rajah 7: Kesediaan Mengajar Di Sekolah Bukan Kerajaan dan Bukan Opsyen

\section{Kesediaan Mengajar Di Sekolah Bukan Kerajaan dan Bukan Opsyen}

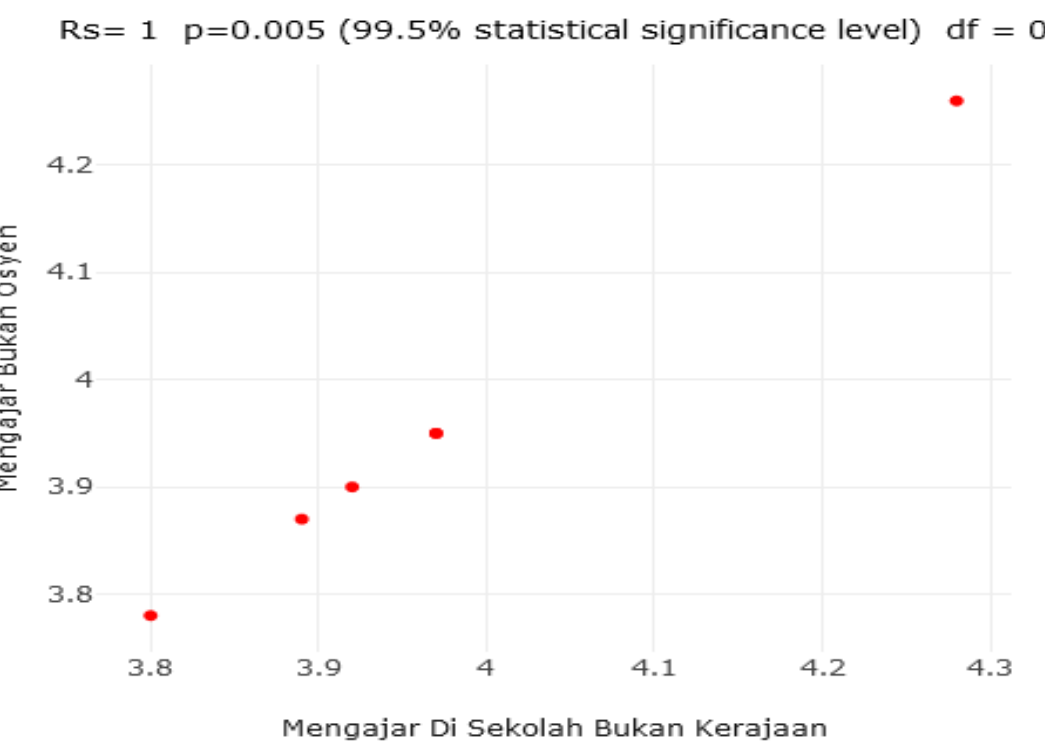

\section{Kesediaan Mengajar di Sekolah Bukan Kerajaan}

Dapatan kajian yang diperoleh menunjukkan bahawa kesediaan pelajar-pelajar Program Pendidikan Sejarah terhadap penerimaan mengajar di sekolah bukan kerajaan adalah pada tahap tinggi. Hasil dapatan juga membuktikan bahawa pelajar-pelajar Program Pendidikan Sejarah tetap merasakan bersyukur jika mendapat tempat untuk mengajar di sekolah bukan kerajaan. Telah diketahui bahawa Program Pendidikan Sejarah adalah "open market" dan UMS atau kerajaan tidak terikat dengan tawaran penempatan mengajar di sekolah kerajaan. Oleh yang demikian, pelajar-pelajar Program Pendidikan Sejarah seakan memahami apabila didapati mereka bersedia untuk membuat penyesuaian diri setelah mendaftar berkhidmat di sekolah bukan kerajaan. Malah, hasil dapatan juga membuktikan bahawa kebanyakan bersedia berkhidmat di sekolah bukan kerajaan tanpa sebarang rungutan. Oleh yang demikian, penerimaan mereka terhadap penempatan mengajar yang ditawarkan walaupun sekolah bukan kerajaan dan terpaksa berjauhan dengan keluarga adalah benar. Namun begitu, mereka tetap juga berperasaan perlu bersedia meneroka pelbagai online atau non-online platform untuk mengembangkan kerjaya guru, jika tidak berpeluang mengajar di sekolah kerajaan mahupun sekolah bukan kerajaan. Contoh: youtube, tik tok, google meet, google classroom, pusat tuisyen, taska, tadika dan lain-lain.

\section{Kesediaan Mengajar Bukan Opsyen}

Hasil dapatan kajian mendapati pelajar-pelajar Program Pendidikan Sejarah boleh terima mengajar mata pelajaran bukan opsyen di sekolah bukan kerajaan mahupun sekolah kerajaan pada tahap yang tinggi. Pelajar-pelajar Program Pendidikan Sejarah UMS didapati akan merasakan bersyukur jika berpeluang mengajar mata pelajaran bukan opsyen di sekolah bukan kerajaan mahupun sekolah kerajaan. Malah, mereka juga bersedia membuat penyesuaian diri untuk mengajar mata pelajaran bukan opsyen di sekolah bukan kerajaan mahupun sekolah kerajaan. Dapatan kajian juga menunjukkan bahawa mereka bersedia mengajar mata pelajaran bukan opsyen di sekolah bukan kerajaan mahupun sekolah kerajaan tanpa sebarang rungutan. Malah mereka turut menerima tanggungjawab mengajar mata pelajaran bukan opsyen di sekolah bukan kerajaan mahupun sekolah kerajaan walaupun terpaksa belajar ilmu berkenaan subjek baru yang diajar. Oleh yang demikian, pelajar-pelajar Program Pendidikan Sejarah bersedia meneroka pelbagai online atau non-online platform untuk mengembangkan kerjaya guru tanpa mengira opsyen. Contoh: youtube, tik tok, google meet, google classroom, pusat tuisyen, taska, tadika dan lain-lain. Situasi ini adalah disebabkan "open market", selain memperoleh ilmu opsyen Sejarah dan pedagogi pendidikan, secara tidak langsung ia juga dapat 
membantu mereka untuk lebih bersedia bagi menyesuaikan diri jika tidak berpeluang mengajar mata pelajaran opsyen. Hal ini kerana menurut Halimah Harun (2006), guru pelatih perlu menunjukkan sikap yang positif terhadap kerjaya perguruan walaupun profesion tersebut agak mencabar dan mempunyai banyak tekanan.

\section{Kesimpulan}

Daripada perbincangan yang telah dilakukan, terdapat beberapa kesimpulan yang dapat dirumuskan bahawa faktor dominan kekosongan jawatan dalam mencari penempatan untuk berkhidmat selain sekolah awam adalah mengajar pendidikan atau mata pelajaran Sejarah di sekolah menengah swasta. Walau bagaimanapun, pelajar-pelajar Pendidikan Sejarah tetap merasakan bersyukur jika mereka ditakdirkan untuk mengajar di sekolah bukan kerajaan dan bukan opsyen. Mereka juga bersedia menggalas tanggungjawab di tempat bertugas tanpa banyak rungutan. Memandangkan susah mendapat pekerjaan pada era pasca pandemik Covid-19. Menyedari keperluan mengikut semasa, pelajar-pelajar Pendidikan Sejarah juga bersedia melengkapkan diri dengan kemahiran meneroka pelbagai online atau non-online platform untuk mengembangkan kerjaya guru tanpa mengira opsyen. Contoh: youtube, tik tok, google meet, google classroom, pusat tuisyen, taska, tadika dan lain-lain.

\section{Rujukan}

Andrew T. Jebb, Vincent Ng and Louis Tay. (2021). A Review of Key Likert Scale Development Advances: 1995-2019. West Lafayette, IN, United States: Purdue University.

Bar, F. (2021). What Is Descriptive Research? USA: Invoke.

Bui, B., \& Porter B. (2010). The Expectation-Performance Gap in Accounting Education: An Exploratory Study. Accounting Education 19, (1-2), 23-50.

Cai Y. (2012). Graduate Employability: A Conceptual Framework for Understanding Employers' Perceptions. Higher Education, 1-13.

Clarke, M. (2008). Understanding and managing employability in changing career contexts. Journal of European Industrial Training, 3 (4), 258-284

David, N. (2005). The Employment of History Graduates. London: The Higher Education Academy Subject Centre for History, Classics \& Archaeology.

Embi, M. A. (2011). Guide to Effective Teaching \& Learning Practices. Educator \& Trainer in eLearning at Universiti Kebangsaan Malaysia (UKM). Bangi: UKM.

Eric, S. K. (2015). Engineering graduates' skill sets in the MENA region : a gap analysis of industry expectations and satisfaction. European Journal of Engineering Education.

Faris Fuad. (2021). Announcement of special teacher recruitment. Daily News Julai 6, 2021.

Harun, H. (2006). Interest, Motivation and Teaching Skills of Trainee Teachers. Journal of Education, $31,83-96$

Harvey, L. (2001). Defining and measuring employability. Quality in Higher Education, 7(2), 97-109

Hidayah Hairom. (2021). MOE Opens Special Recruitment of 18,702 Grade DG41 Teachers. Daily Shine, Jun 20, 2021.

Ihsan Noorzali. (2021). Recruitment of new teachers: MOE is expected to prioritize graduates of the Bachelor of Education, Institute of Teacher Education. Daily News, Ogos 1, 2021.

Latisha Shafie \& Surina Nayan. (2010). Employability Awareness among Malaysian Undergraduates. International Journal of Business and Management, 5(8).

Malaysia. (2010a). Higher Education Statistics of Malaysia 2009. Putrajaya: Ministry of Higher Education.

McQuaid R, Linda C. (2005). The concept of employability. Urban Studies, 42(2), 197-219.

Mudhovozi, P. 2021. Social and academic adjustment of first-year university students, Journal of Social Sciences, 33(2)251-259.

Pegg A, Waldock J, Hendy-Isaac S, Lawton R. (2012). Pedagogy for employability. New York: The Higher Education Academy.

Saul McLeod. (2019). Likert Scale Definition, Examples and Analysis. USA: Simply Pschology. 
Sewell P, Dacre Pool L. (2010). Moving from conceptual ambiguity to operational clarity. Employability, enterprise and entrepreneuship in higher education. Education and Training, 52 (1), 89-94.

Yee Ting Ngoo, Kui Ming Tiong, Wei Fong Pok. (2015). Bridging the Gap of Perceived Skills between Employers and Accounting Graduates in Malaysia. American Journal of Economics, 5(2), 98-104. 